\title{
China-Raw Materials: a controversial step towards evenhanded exploitation of natural resources
}

\author{
MARCO BRONCKERS* \\ Professor of Law, Leiden University \\ KEITH E. MASKUS* * \\ Professor of Economics, University of Colorado Boulder
}

\begin{abstract}
This case sheds light on the question whether WTO members, when exploiting their natural resources, can give priority to the needs of their domestic market as opposed to the needs of other WTO Members. From the ruling of the Appellate Body, and the unappealed part of the panel decision, one can conclude that a WTO Member normally must ensure an evenhanded distribution of the natural resources that it decides to mine or harvest amongst the WTO membership. The only difference arises where a Member's citizens or industries face a crisis because of a temporary shortage of an essential product. For those who share an international outlook on the world, this is an acceptable, and even a desirable outcome. The ruling potentially has far-reaching implications for international trade, not only in minerals and metals, but for agricultural and energy goods as well. However, in reaching this laudable result, circumscribing the use of export restrictions, the Appellate Body also made a highly regrettable finding. It ruled that China, because of the wording of its Accession Protocol, was not allowed to invoke a public policy justification for certain of its export restrictions (notably: its export duties, on which it had assumed additional commitments). The underlying assumption that sovereign states can sign away their rights to pursue public policies, such as environmental protection, which are generally admitted amongst the WTO membership, is deplorable.
\end{abstract}

\section{Introduction}

In this paper we analyze China-Measures Related to the Exportation of Various Raw Materials (hereinafter China-Raw Materials). ${ }^{1}$ The dispute involved claims by the United States, Mexico, and the EU that China had sustained WTO-inconsistent

\footnotetext{
*Email: Marco.Bronckers@vvgb-law.com.

**Email: Keith.Maskus@colorado.edu.

1 The Appellate Body Report is document AB-2011-5 (30 January 2012). It is a combined report containing the Appellate Body's statements regarding individual disputes in documents WT/DS394/AB/R; WT/DS395/AB/R; WT/DS398/AB/R.
} 
export restrictions on key natural resources, with the effect of diminishing the access of foreign downstream firms and customers to those resources. As we discuss below, in most respects these restrictions were problematic under WTO rules. Indeed, China was unable to defend them on either of two grounds. China failed to justify an exception for its export measures under GATT Article XX(g), which permits such measures relating to the preservation of exhaustible resources. ${ }^{2}$ Nor could Beijing sustain a claim under GATT Article XI.2(a), which allows quantitative export restraints that are temporary and aimed at preventing shortages of products essential to its economy. ${ }^{3}$

However, one interesting and novel aspect of the case is that these policies were inconsistent with China's WTO Accession Protocol, in which Beijing agreed, through negotiations with existing WTO members, to limit greatly its recourse to export restraints in raw materials. Both the Panel Report and the Appellate Body $(\mathrm{AB})$ ruling turned on this self-denial - with the $\mathrm{AB}$ going a step further than the panel and denying China even the possibility to justify deviations from its additional commitments on export restraints by appealing to traditional public policy exceptions such as environmental protection.

Before turning to the facts of this case, it is useful to place it into a broader social and economic context. As others have noted, ${ }^{4}$ in recent years countries have imposed, with increasing frequency, restrictions on exports of primary commodities, especially agricultural goods. For example, during the 'food crisis' of 2007-08 more than 30 nations limited exports of staple foodstuffs in order to ensure domestic supplies and minimize increases in food prices in the face of public protests. A recent study of 21 metals and minerals commonly used in industrial applications found that export restraints of some kind were imposed in all of these commodities by major exporting nations at some point between 1999 and 2009.5 The bulk of these came in 2007-08, again coincident with global price spikes in raw materials. As of 2012, at least 33 countries have in place bans on various forms of $\log$ and timber exports. ${ }^{6}$ The bulk of these policies, however, have been in place for decades.

2 The General Agreement on Tariffs and Trade (GATT 1994): Article XX: General Exceptions.

3 The General Agreement on Tariffs and Trade (GATT 1994): Article XI: General Elimination of Quantitative Restrictions.

4 See Baris Karapinar, Export Restrictions and the WTO Law: 'Regulatory Deficiency' or 'Unintended Policy Space', Berne: World Trade Institute; NCCR Trade Regulation Working Paper no. 2010/11, May 2010; Robert Howse and Tim Josling, Agricultural Export Restrictions and International Trade Law: A Way Forward, International Food and Agricultural Trade Policy Council, 2012.

5 Jane Korinek and Jeonghoi Kim, Export Restrictions on Strategic Raw Materials and Their Impact on Trade, Trade Policy Paper no. 95, Paris: OECD, 2010.

6 'National Export Bans and Restrictions,' compilation available at http://risk.forestlegality.org/files/fla/ Export_bans_restrictions_2012_06.pdf. 
It is not yet clear whether the increasing use of export restraints is a temporary (or perhaps intermittent) reaction to price volatility in global commodity markets or is becoming a systemic presence in trade policy for structural reasons. If the former, the solution is most properly found in means of dealing with the underlying volatility. ${ }^{7}$ It seems likely, however, that outside of agriculture, export barriers in natural resources are imposed to achieve various longer-term objectives. As described in Section 4, these may range from simple protectionism - a strong element of the Chinese restraints considered here, properly disciplined by the $\mathrm{AB}-$ and government revenue generation to preservation of exhaustible resources and limitation of environmental externalities.

These last two factors surely will become increasingly significant priorities in national policymaking. Rapid growth in the global demand for raw materials to fuel industrialization, driven to a great degree by China itself, will place further pressures on resource supplies and reserves in numerous countries. These pressures again have found voice at the WTO in the ongoing case alleging that China illegitimately restricts exports of rare earths, which are critical inputs in several hightechnology products. ${ }^{8}$ And, as we describe later, US administrative licensing requirements for the exportation of natural gas could fail scrutiny under WTO rules. More broadly, both the extraction and use of these resources embody environmental risks that must be addressed, generally by national public policy. In this context, it is our view that a rigid WTO approach that asymmetrically precludes such policy space on the part of certain countries is not sustainable.

\section{The facts}

In late 2009, a panel was charged with examining complaints about China's export barriers on certain raw materials used as inputs in industrial goods. The complainants were the United States, Mexico, and the EU, though 13 other countries asserted third-party rights. The three filing countries argued that the export restrictions, including export tariffs, quantitative barriers, minimum export prices, and certain administrative procedures, were inconsistent with China's obligations under its WTO Accession Protocol' ${ }^{9}$ (including the Working Party Report on the Accession) and also with GATT rules. The commodities subject to restraints in the abuse were certain forms of bauxite, coke, fluorspar, magnesium, manganese, phosphate (yellow phosphorus), silicon metal, silicon carbide, and zinc.

The complaints claimed that China's policy improperly imposed the following forms of export restraints. First, that there were quantitative restrictions, mainly

7 Of course, a considerable part of that volatility stems from import protection in agriculture that is little disciplined by the WTO; see Howse and Josling, Agricultural Export Restrictions and International Trade Law, supra note 4.

8 China-Measures Related to the Exportation of Rare Earths, Tungsten and Molybdenum (DS432).

9 Protocol on the Accession of the People's Republic of China, WT/L/432, 23 November 2001. 
quotas, that violated the GATT Article XI general ban on quantitative export or import restrictions, China's Accession Protocol, and the Working Party Report. Second, that China imposed export taxes on these goods, in violation of the Accession Protocol and the Working Party Report. Third, that China sustained minimum export price requirements on certain commodities. Finally, that China used administrative means to restrict exports, including licensing requirements and unwarranted fees and formalities, and that many such policies were not published adequately and were not discharged in a manner that was 'uniform, partial, and reasonable'.

That such restrictions were in place was not contested. For example, China sustained export quotas of 930,000 tons of bauxite in 2009 and 2010. In those same years, there were quotas of 550,000 tons of fluorspar, 216,000 tons of silicon carbide, and around 1.4 million tons of magnesium carbonate, among others. ${ }^{10}$ China also makes extensive use of export duties. As of 2010, more than 300 HS 8 -digit tariff lines were subject to export tariffs (those in the basic schedule), interim export taxes (imposed on a temporary basis), or both. ${ }^{11}$ These categories included all of the raw materials involved in this dispute, though there was some variability at the tariff line level within each broad commodity group. For example, within the bauxite group one category of pure (not alloyed) aluminium bore a 30\% export tariff, while another carried the same tariff plus a $15 \%$ interim tariff, as did alloyed aluminium and aluminium scrap. Fluorspar, magnesium, and some categories of manganese, phosphate, silicon, and zinc were subject to interim export duties ranging from $5 \%$ to $35 \%$, while coke carried a $40 \%$ charge.

Export duties are not generally inconsistent with GATT rules. The problem in this case, however, is that in its Accession Protocol, China put forward an annex that listed just 84 tariff lines on which it reserved the right to impose such taxes, formally giving up its right to impose such taxes on other goods. Indeed, Article 11.3 of the Accession Protocol states that 'China shall eliminate all taxes and charges applied to exports unless specifically provided for in Annex 6 of this Protocol or applied in conformity with the provisions of Article VIII of the GATT 1994.' The schedule in Annex 6 offered a bound rate on the included items and China's applied export taxes were often below this level, though they could be raised to the bound rate at the country's discretion. In fact, China seems to revise its export taxes often, evidently in response to shifts in market conditions and world prices.

Regarding the other elements of the complainants' case, upon investigation the Panel report found that Chinese policy required firms to export certain categories of

10 Government of China, Ministry of Commerce, Announcement number 83 (2008), 'Total Amount of Export Quotas of Agricultural and Industrial Products'.

11 Government of China, Circular on the Customs Tariff Commission of the State Council on the Tariff Execution Plan of 2010, compiled by Karapinar, Export Restrictions and the WTO Law, supra note 4. Another category called 'special export tariffs' applied in a few cases. 
bauxite, coke, fluorspar, magnesium, silicon carbide, yellow phosphorus, and zinc at minimum export prices (MEPs), which were coordinated by the authorities. ${ }^{12}$ Such MEPs are inconsistent with GATT rules and are therefore impermissible means of facilitating export taxes. The Panel report also found that certain provisions of its export licensing regime in the disputed products gave the authorities unwarranted discretion, raising sufficient uncertainty for competitors that it amounted to an impermissible export restriction. ${ }^{13}$

As noted, there were three complainants, the United States, Mexico, and the EU. Under its authority, in 2009 the Dispute Settlement Body created a single WTO Panel to hear all three cases. ${ }^{14}$ A joint Panel report was issued in July, 2011, with a common narrative of facts but somewhat different findings. China and the three complainants each appealed portions of the report. The Appellate Body issued its findings in January 2012,15 and that report $(\mathrm{AB})$ is analyzed in what follows.

\section{The litigation}

The complainants (EU, Mexico, and the United States) argued that most of China's export restraints violated several GATT principles (VII, X, and XI), and that China's appeal to exceptions (regarding critical shortages in XI, and regarding conservation measures in XX) was not justified.

Furthermore, in respect of China's export duties, the complainants argued that China violated its WTO-plus commitment in its Protocol of Accession not to impose such duties. ${ }^{16}$ The complainants rejected attempts by China to justify this violation under XX GATT, arguing that this public policy exception in the GATT Agreement was not available in respect of China's commitment on export duties in its Protocol of Accession.

The panel found fault with China for having maintained the five categories of WTO-illegal measures mentioned above: export duties, export quotas, export quota administration and allocation, export licensing requirements, and minimum export price requirements. ${ }^{17}$ On appeal, the Appellate Body threw out about

12 China-Raw Materials, AB-2011-5, paragraph 8.

13 Ibid.

14 The cases are WT/DS394/R (China-Measures Related to the Exportation of Various Raw Materials (Complainant:United States)); WT/DS395/R (China-Measures Related to the Exportation of Various Raw Materials (Complainant: European Communities)); and WT/DS398/R (China-Measures Related to the Exportation of Various Raw Materials (Complainant: Mexico)), 5 July 2011.

15 China-Raw Materials, AB-2011-5.

16 Article 11.3 of China's Protocol of Accession. In Annex 6 to its Protocol, China was exceptionally allowed to maintain export duties, up to a certain maximum, in respect of 84 listed products (of the disputed raw materials, only yellow phosphorus appeared on this list of exceptions, and the panel found that China had not exceeded the allowed maximum of its export duty; see China-Raw Materials, fn 553).

17 See the findings of the WTO combined Panel Reports, China-Measures Related to the Exportation of Various Raw Materials (5 July 2011). 
half of the panel's findings at China's request, on the ground that the complainants had not sufficiently identified a series of measures and the legal objections they were formulating in their regard as required by Article 6.2 DSU. According to the Appellate Body, the fact that China might have been able to defend itself against such inadequately formulated allegations did not mean that the complainants had complied with this due process provision. ${ }^{18}$ As a result, the remaining case centered on two categories of measures: export duties and export quotas.

With respect to the justification China had offered for its export quota, the $\mathrm{AB}$ agreed with the panel that China's measure did not fit the conditions of Article XI.2(a) which limits ${ }^{19}$ the prohibition on quantitative restrictions expressed in Article XI.1. According to paragraph 2(a), the restrictions have to be 'temporarily applied', with a view to 'prevent or relieve critical shortages' of essential products. On the first condition of temporary application, the Appellate Body distanced itself from the panel and clarified that the duration of a temporary restriction did not have to be fixed in advance. ${ }^{20}$ Thus, the restriction could end whenever the temporary situation it was designed to address ended. On the second condition, the Appellate Body agreed with the panel that resource depletion does not amount to a critical shortage within the meaning of Article XI.2 GATT. The Appellate Body reiterated the panel's finding that the measure had been in place for at least a decade, and the panel's supposition that China intended to maintain its measure for another 16 years, i.e. the period estimated its reserve might last. ${ }^{21}$

The panel had also found that China's export quota could not be characterized as a conservation measure regarding an exhaustible natural resource, within the meaning of Article XX(g) GATT. China accepted this particular finding, but (apparently with an eye to future cases) appealed another finding of the panel on $\mathrm{XX}(\mathrm{g})$. According to the panel, a conservation measure within the meaning of XX (g) would have to satisfy two conditions: (i) the export restriction would have to be applied jointly with restrictions on domestic production or consumption, and (ii) the purpose of the export restriction would have to be to make effective the restriction on domestic production or consumption. China argued that the second condition imposed by the panel was unwarranted, and the AB agreed. Still, this particular win did not change the outcome of the case, as China had not appealed the panel's other findings in respect of $\mathrm{XX}(\mathrm{g})$.

18 China-Raw Materials, paragraph 233.

19 See China-Raw Materials, paragraph 334. This wording suggests that paragraph 2(a) would not set forth an exception to the prohibition of paragraph 1. In that event, a complainant should be charged with the burden of proving that the conditions of paragraph 1 are met and that the conditions of paragraph 2 are not met, in order to make a prima facie case that the defendant's measure infringes Article XI, or at least Article XI.1.

20 China-Raw Materials, paragraph 331.

21 China-Raw Materials, paragraph 340. 
Furthermore, in respect of China's export duties, which it had found to be in violation of China's commitments under its Protocol of Accession, the panel had refrained from deciding whether China was at liberty to appeal to Article XX. Relying on the principle of judicial economy, the panel instead had investigated the merits of China's claim under XX, and had found that China's appeal would fail in any event. The $\mathrm{AB}$ disagreed with the panel that the question of principle could be avoided. It then found that, because of the wording of China's Protocol of Accession, China had forfeited the right to appeal to the public policy exceptions of $\mathrm{XX}$ in respect of its additional commitment in respect of export duties.

\section{Legal assessment of the ruling}

As far as the critical shortages exception goes in Article XI.2(a), it makes sense to interpret this provision narrowly as the Appellate Body has done. Broader or longer term concerns about environmental protection or conservation can be addressed through Article XX, notably in paragraph (g). This was illustrated in the panel's ruling on the merits of China's appeal to Article XX $(\mathrm{g})$, although the panel ultimately did reject China's appeal to this exception in the present case as well. More specifically, the panel did not find any evidence that the export quota on bauxite was maintained for conservation purposes ${ }^{22}$ (for the most part China did not appeal this part of the panel's ruling in respect of quantitative export restrictions; and the one point on which it did appeal, discussed above, led to an unobjectionable relaxation of the conditions of subparagraph $(\mathrm{g})$ by the $\mathrm{AB})$. In other words, a narrow interpretation of 'critical shortages' in Article XI.2, coupled with a sensible interpretation of the 'conservation' exception of Article XX $(\mathrm{g})$, makes it more difficult for WTO Members to maintain quantitative export restrictions that beggar their neighbors. This part of the Appellate Body's (and of the panel's) ruling is to be welcomed.

On the other hand, that the Appellate Body denied China the mere possibility of appealing to Article XX to try to justify its additional commitment on export duties is strongly objectionable. There is no good reason why a public policy exception would not be available to commitments regarding export duties, whereas they are available in respect of quantitative export restrictions. Both types of restrictions are comparable. In other words, admitting public policy exceptions in respect of a commitment on export duties does not necessarily open the door to admitting an appeal to Article XX in respect of other commitments on goods, such as for example the obligations set forth in the WTO Agreement on Subsidies and Countervailing Measures (SCM). ${ }^{23}$

22 See panel ruling, supra note 17, at paragraphs 7.411-7.435.

23 We might add that we see no strong objection either to admitting these public policy exceptions in respect of other WTO commitments regarding trade in goods - though admitting an appeal to Article XX in respect of commitments in the SCM could effectively re-create a category of non-actionable subsidies. 
Another problem with denying China the right to appeal to public policies to justify export duties is that other new WTO Members, such as the Ukraine, were granted the right in their Protocols of Accession to invoke Article XX in respect of their WTO-plus commitments not to impose export duties. ${ }^{24}$ The WTO's original idea was to create a single package, that is, one set of rules for all WTO Members, at least for those groups of WTO Members that were economically similarly situated-developed, developing, and least-developed countries. Without a firm design or explicit decision, a trend has crept in to add more and more commitments in the protocols of accession of new WTO members. From a systemic perspective, this unruly development of a two-speed, or even a multi-speed régime of WTO obligations, depending on the time of accession rather than on the economic position of a member, is questionable. ${ }^{25}$ But it surely becomes objectionable if and to the extent generally accepted public policies, such as environmental protection, to justify possible deviations from a WTO obligation cannot be invoked by all WTO Members in respect of the same type of obligation.

When reading the $\mathrm{AB}$ report, and its traditional focus on textual nuances, one gets the sense that China made a drafting error when negotiating this particular WTO-plus commitment on export duties. China could have insisted on public policy exceptions but it did not do so, or at least not clearly enough. (It is notable that in an earlier case the Appellate Body, again on textual grounds, did grant China the right to appeal to Article XX in respect of other additional commitments in China's Protocol of Accession.) ${ }^{26}$ Holding China to a drafting error is a deplorable outcome. We are not looking at a private contract, where parties can more easily choose to contract out of certain rights or be held to their negotiating mistakes. Here, we are looking at the rights and duties of sovereign states to regulate the public good. Notions of 'contracting out', or 'negotiating mistakes', are entirely misplaced here.

In other cases, the $\mathrm{AB}$ has chosen a much wiser outcome, and has not let itself be (mis)guided by anomalies in the text of the WTO Agreements. Recall, for instance,

This might be seen to create a tension with the WTO membership's explicit engagement that the exceptions for non-actionable subsidies in the SCM would disappear as they did not agree to extend these after 2000 (see Article 31 SCM). But, of course, admitting an appeal to Article XX would not revive the particular exceptions for non-actionable subsidies that were once included in the SCM. Accordingly, there would not be a real conflict between admitting an appeal to Article XX in respect of the SCM, and the drafters' omission to extend certain specific rules on non-actionable subsidies.

24 Report of the Working Party on the Accession of Ukraine, WT/ACC/UKR/152, 25 January 2008, at paragraph 240.

25 See M. Tiyagi, 'Flesh on a Legal Fiction: Early Practice in the WTO on Accession Protocols', 15 Journal of International Economic Law 391-441 (2012).

26 Appellate Board Report, China-Measures Affecting Trading Rights and Distribution Services for Certain Publications and Audiovisual Entertainment Products (DS363), at paragraphs 216-233 (21 December 2009). Having recognized China's right to invoke GATT Article XX(a) in respect of certain mechanisms to review the content of imported reading materials and audiovisual products, the AB ultimately rejected China's appeal to this public policy exception as unwarranted. 
how the $\mathrm{AB}$ stretched and squeezed the accordion in interpreting 'like products' differently within the same Treaty article (III.2 and III.4 GATT), appealing to the rationale of the provision to interpret the same words flexibly and differently. ${ }^{27}$ In the case at hand, the Appellate Body could have given more weight, for instance, to language in other parts of China's accession documents. ${ }^{28}$

The fault is not just the Appellate Body's though. It is remarkable to see how informally, or even haphazardly, additional obligations are being created for new WTO Members in their accession documents - and this is unfortunately true too for the recognition of their right to invoke the classic public policy exceptions in respect of these WTO-plus commitments. These additional obligations, and eventual exceptions, are not framed in classic treaty language, or by a methodical reference to the WTO package of agreements. Rather, most of these additional obligations and their supposed exceptions are recorded in what are really extended meeting minutes: dozens, if not hundreds of pages of working party reports, drawn up during the accession negotiations. These protocols or reports do not follow a particular format or system. Yet, as the present case shows, when they are being examined through the rigors of WTO dispute settlement, these informally drafted documents are being held to the same standards as a formal treaty text.

This situation leaves open too many important points for discussion. Rather than 'constructive ambiguity', we are left with 'hazardous interpretative questions'. At the end of long and complicated exchanges, negotiators may be unwilling to take the time to recast their efforts into a solid treaty text, which can be more easily reviewed and dissected - first by domestic parliaments, and then in case of a dispute by national or international tribunals. But, as the present case shows, important public policies may be at stake in WTO accession negotiations. Without a thorough and sufficiently open debate amongst all stakeholders, on the basis of a precise text, these public policies should not be considered contracted out or excluded through drafting errors.

Finally, it is noteworthy too that none of the WTO Members intervening in this case (Canada, Colombia, Japan, Korea, and Turkey) took a more principled

27 Appellate Body Report, European Communities-Measures Affecting Asbestos and AsbestosRelated Products (DS135), at paragraphs 88, $96 \mathrm{ff}$ (12 March 2001).

28 See, e.g., paragraph 170 of China's Accession Working Party Report, in which China committed that its laws and regulations relating to, amongst others, 'taxes levied on imports and exports', would be 'in full conformity with its WTO obligations'. The Appellate Body dismissed the relevance of this paragraph, despite its explicit reference to export taxes, as being concerned only with 'internal policies'. See ChinaRaw Materials, paragraph 298. The least one can say is that this was not the only possible interpretation of the words. For different textual, contextual, and teleological arguments allowing China to invoke Article XX in this case, see, e.g., E. Baroncini, 'The Applicability of GATT Article XX to China's WTO Accession Protocol in the Appellate Body Report of the China-Raw Materials Case: Suggestions for a Different Interpretative Approach', 1 China-EU Law Journal 1-34 (2012); Julia Ya Qin, 'Editorial Comments - The Predicament of China's "WTO-Plus" Obligation to Eliminate Export Duties: A Commentary on the China-Raw Materials Case', 11 Chinese Journal of International Law 237-246 (2012). 
approach. They all agreed with complainants that China should not be allowed to appeal to XX in respect of its export duty commitment, only Korea doing so with some reluctance. It may well be that these interveners, as well as the complainants, were upset by what they saw as China's attempts to back out of a particular bargain they thought they had struck. And because they were so upset, all of them fought hard to minimize China's chances of prevailing in the case, amongst others by denying China the right to invoke any kind of exception in Article XX. Even if one appreciates that this was a litigation tactic, wiser counsel should have prevailed in these countries' capitals. The fight should only have been on the merits of China's contention that its export duties were justified for environmental reasons; a contention which, it will be recalled, the panel rejected. Denying a member the mere right to invoke generally accepted public policies reflects badly on an organization like the WTO, and tarnishes its legitimacy.

\section{Economic assessment of the ruling}

We offer brief commentary on three economic aspects of this case: the welfare implications of export restraints in raw materials and the potential for economic harm to industries in other countries, the weakness of China's Article XX defense, and efficiency concerns raised by the strict enforcement of the WTO-plus Accession Protocol terms.

\section{Basic economic implications}

There are several reasons why countries may restrict exports, particularly of agricultural commodities and raw materials. One is to raise government revenues by taxing resources that are essentially immobile, while shifting some of the burden of the tax onto foreign customers. This strategy can be particularly effective if the commodities face inelastic world demand and have few medium-term substitutes in use, a situation that arguably characterizes some of the raw materials in this dispute. There is little indication that China generated much public revenue from the export taxes in question, however, while its resort to export quotas and licensing, with exportation rights evidently not subject to public auction, suggests that quota revenues were not of interest to authorities.

A second objective is to generate scarcity of raw materials, forcing up the gross (restriction-inclusive) price paid by foreigners for Chinese commodities. This strategy can generate net gains for the exporting nation under essentially two conditions: relatively inelastic world demand (supporting a notable terms of trade gain) and a significant share of world exports (so the price increase applies to a large volume). The latter element is critical; if China is not a major supplier its export barriers would have no real impact on world prices.

Again, short-run demand inelasticity may apply to some of the materials here (e.g., bauxite, fluorspar, manganese, silicon, and zinc, which are key industrial inputs). It is hard to argue, however, that Chinese exports are sufficiently large as to 
afford it pricing power in many of these goods. ${ }^{29}$ In 2008, for example, the world export shares of the materials in question were: bauxite $(0.2 \%)$, zinc $(0.7 \%)$, phosphate $(6.2 \%)$, manganese $(6.7 \%)$, fluorspar $(8.2 \%)$, coke $(33.6 \%)$, magnesium $(43.5 \%)$, and silicon $(45.2 \%) .{ }^{30}$ Further, these shares are subject to considerable change from year to year. Indeed, the volume of Chinese exports in bauxite and zinc fell considerably in the 2000s and the country is now a major net importer of those metals and manganese. It seems unlikely that China would set out to engineer an increase in the global price of a commodity it imports significantly. This leaves coke, magnesium, and silicon, in which China has large export shares. Coke, however, has numerous substitutes as a fossil fuel and, in fact, the country's export share fell considerably from 2002 to 2008.

Perhaps driving up the international prices of at least magnesium and silicon supplies was a goal of these restrictions. Certainly, the costs of these materials rose dramatically in 2007-08, with the US free-market price of silicon metal doubling and that of ferro-manganese nearly doubling. ${ }^{31}$ It is not possible to determine whether China's export restrictions were a significant causal factor. It seems unlikely, however, for at least three reasons. First, similar price spikes happened for many raw materials in this period and numerous factors were involved. Second, the export tariffs had been in place for many years prior to these price increases. Third, these prices fell back to their 2007 levels by early 2009, suggesting that world economic conditions (the great recession) are their primary determinant, rather than individual country tariff policy.

This does not mean that prices were unimportant in policy formation, however. Even if they did not push up world prices significantly, China's export quotas and taxes drove a notable wedge between them and domestic charges. For example, from January 2007 through January 2010, the prices of ferro-silicon in China were sustained at about $\$ 300$ less per metric ton (or about $20 \%$ of the mean European price in those years) than those in Europe, with a somewhat smaller gap between China and the United States. ${ }^{32}$ In silicon metal, the gap between domestic Chinese (Hong Kong) prices and US and European prices ranged between $\$ 1,000$ and $\$ 2,000$ per ton (about $50 \%$ of the latter levels). The margins were much smaller in ferro-manganese, but still favored lower Chinese prices. In short, Chinese export restraints did not diminish world, or even domestic, price volatility by much, if any, but they did sustain significantly lower prices at home.

This observation likely explains the real Chinese motivation and, indeed, the third general objective of export restrictions in raw materials. They offer a

29 The situation in rare earths, currently under dispute, could be quite different as Chinese exports often account for more than $90 \%$ of US, EU, and Japanese imports. See Oana Maria Stanculescu, China's Rare Earth Trade Analysis, Babes-Bolyai University, 2011.

30 Karapinar, Export Restrictions and the WTO Law, supra note 4.

31 Karapinar, Export Restrictions and the WTO Law, supra note 4.

32 Karapinar, Export Restrictions and the WTO Law, supra note 4. 
substantial input-cost advantage to domestic producers of goods that make use of these industrial materials. In this context, the trade restraints may be interpreted as a form of industrial policy aimed at supporting growth in such industries as aluminium products, steel, batteries, fertilizers, certain chemicals, and semiconductors. Indeed, since these downstream industries did not face such export restraints, the policies amounted to significant effective rates of subsidy. In turn, the subsidies penalized downstream competitors in other countries, both through having to pay potentially higher input prices and failing to have access to the cheaper Chinese raw materials. Of course, this downstream competitiveness threat was the genesis for the WTO complaints. ${ }^{33}$ China is a major producer and exporter in some of these key industries, including steel, semiconductors, and dry cell batteries.

\section{China's defense}

Seen through this lens, the motivation for the export restrictions was simple industrial protection. Again, had China not signed away its prerogative to deploy export taxes in its Accession Protocol, the duties could have been defended as consistent with the WTO under Article XI(1). The export quotas and licensing requirements could be defended under XI(2) only if they were temporarily needed to safeguard against critical shortages of essential products or if they were necessary to meet standards and classification or marketing requirements. China simply could not defend its policies on these grounds, for they had been in place for so long that the export restraints could not reasonably be considered temporary or aimed at dealing with critical shortages. Nor could they be deemed necessary to meet standards or marketing rules in global trade.

Thus, China's only recourse was to justify the export barriers under Article XX covering general exceptions. In particular, $\mathrm{XX}(\mathrm{g})$ permits countries to adopt measures 'relating to the conservation of exhaustible natural resources if such measures are made effective in conjunction with restrictions on domestic production or consumption'. China had to demonstrate that its restrictions were aimed specifically at conserving exhaustible natural resources, while meeting the 'balancing requirement' that they must be combined with domestic production and consumption preservation measures.

It is generally hard to make this case and China failed to do so in the dispute, notably at the panel level. An exhaustive listing of China's mining and extraction laws, along with its environmental protection laws, found them to be fragmented

33 It is difficult to isolate such impacts on foreign competitors. One of the authors performed a straightforward statistical comparison of Chinese export growth rates in major downstream industries in the United States, Mexico, and the EU-27, finding no significant differences between them. Nor were there any correlations between differences in such export growth rates in affected downstream sectors versus similar products that did not use the restricted inputs in China and similar differences in the other countries. A more systematic study might identify such impacts, however. For further details, contact Keith Markus at keith.maskus@colorado.edu. 
and aimed at policies of little relation to the trade restraints. ${ }^{34}$ The mining laws in particular attempt to manage environmental damages from extracting but not to curtail production for conservation purposes. These laws are also poorly enforced. Provinces may impose a severance tax but they are small in relation to price, do not correspond to export restrictions, and cover only a subset of materials in the case. Most importantly, no tax or conservation policies were aimed at limiting domestic production or consumption in downstream sectors and products. Thus, there were no discernible efforts by China's government to limit production of downstream sectors in this period or to tax outputs.

In sum, the export taxes and quotas China imposed on raw materials should be construed as protectionist elements of trade policy, rather than a bulwark for environmental protection or sustainable development. Seen in this light, the findings of the panel in particular, denying China's defenses on the merits, were in line with WTO principles.

\section{The WTO-Plus Issue}

Based on this review, we are untroubled by the basic thrust of AB's rulings. One issue of concern remains, however. Suppose that China had been able to show that its export restraints had, in fact, met the balancing requirement in $\mathrm{XX}(\mathrm{g})$ and were legitimately aimed at conservation of exhaustible resources. The Appellate Body's literal interpretation and enforcement of the Accession Protocol, even to the point of concluding that China had intended to forego its rights, suggests that new entrants to the WTO that accept similarly ambiguous language cannot avail themselves of Article XX to pursue measures that meet otherwise acceptable public policy goals.

If that principle is embedded into the WTO, it raises an obvious question of equity: why should new entrants, most of which are likely to be poor developing or transition countries, have to accept asymmetrical (WTO-Plus) obligations, in respect of which they might not even be able to invoke traditional public policy exceptions? Because it is more restrictive than the policy space afforded existing members, the idea flies in the face of the concept of special and differential (i.e., less restrictive) treatment on behalf of poorer nations. This seems an odd - and overly prescriptive-element for existing WTO members to demand in their negotiations with entrants. It is reminiscent of some of the development and trade debates from decades ago.

It also raises at least three efficiency issues worth debating. First, the restrictive nature of this WTO-Plus and Minus principle (plus, in respect of obligations; minus in respect of public policy exceptions) could deter some countries from joining, leaving them on the side of the multilateral trading system. Second, respect for the WTO system could be eroded over time if some countries are denied the flexibility

34 Karapinar, Export Restrictions and the WTO Law, supra note 4. 
to deal with public-policy goals, using the same instruments, that other countries enjoy. Third, the asymmetric policy space it leaves between old and at least some ${ }^{35}$ new members is problematic, for it denies opportunities to the latter that could conflict with the former. If traditional members choose, going forward, to implement border taxes or export limits to deal with climate change or conserve resources, for example, they would do so presumably under Article XX, including the balancing requirement. If new members are denied the opportunity to do the same, significant risks of asymmetric policies and distortions in resource use could emerge unless additional negotiations took place. One possible example, discussed in the following section, is the limits placed on natural gas exports by the United States. Why should the latter possibly be allowed a public policy exception, while China would be denied the same justification, solely as a function of the timing of entry into the WTO?

\section{Conclusion: evenhanded access to raw materials}

We have criticized the growing asymmetry in WTO-obligations, and especially the Appellate Body's denial of a classic public policy exception (environmental protection) to China in respect of one of its WTO-Plus commitments. Yet regarding the merits of the case it is possible to end on a more positive note.

The implications of the Appellate Body's ruling (coupled with the unappealed part of the panel decision) are far-reaching in a world where natural resources are unevenly distributed amongst the WTO membership, yet where most WTO members are hungry for them. The principle that would seem to emerge from this case is that WTO Members are free in their decision whether or not to mine or harvest their natural resources, or the extent to which they do so. Yet whenever they mine or harvest, they must normally make the natural resources they produce available to other WTO Members as well-except in a case of temporary, critical shortage.

The only legitimate deviation regarding this principle of 'evenhanded' exploitation could be made by original WTO Members, and possibly some of the newer WTO members, as they might seek to reduce exports through the imposition of export duties as GATT 1994 does not discipline them. If only because of their policy objections to the export duties imposed by other countries, however, it is not obvious that major WTO members like the EU and the US will want to resort to export duties on any significant scale. It will be interesting to see whether the pending case on China's restrictions on Rare Earths may add nuances here. ${ }^{36}$

35 It is to be recalled that some new Members, while accepting a WTO-plus obligation in respect of export duties, did reserve the right to invoke the classic public policy exceptions in this respect too. For an example, see Report of the Working Party on the Accession of Ukraine, supra, note 24.

36 China-Measures Related to the Exportation of Rare Earths, Tungsten and Molybdenum, supra note 8 . 
The WTO membership probably has not fully signed on to this principle yet. The implications go far indeed. They not only concern minerals and metals, but also agricultural crops. ${ }^{37}$ Another sector to consider is energy. Decisions of WTO Members, such as an OPEC-country like Saudi-Arabia, to cut production of oil in order to boost world market prices, would not be affected by the China-Raw Materials ruling. However, some countries seem to restrict the exports of oil or gas that they do produce.

Recently, attention has been drawn for instance to restrictions imposed by the United States on exports of shale gas. Such exports require approval from the US Department of Energy. ${ }^{38}$ Reportedly, these restrictions help to secure sufficient domestic supply, at prices that do not reflect higher international prices for natural gas. ${ }^{39}$ The US has relaxed these licensing requirements in respect of countries with which it has concluded a free trade agreement (FTA). ${ }^{40}$ The result has been that a country like Japan for the time being is seen to be hampered when seeking shale gas supplies in the US. ${ }^{41}$ The EU as well has expressed concern about US export restrictions on shale gas, and may be seeking relief in the current negotiations on a comprehensive trade and investment agreement with the United States (the so-called TTIP negotiations).

Yet if one accepts the consequences of the China-Raw Materials ruling as analyzed above, US trading partners, including China, might now have a legal claim against the US Government, demanding that it remove the restrictions on exports of shale gas. A non-automatic licensing regime, as maintained by the United States in respect of countries with which it does not have an FTA, could amount to a quantitative restriction infringing Article XI.1. ${ }^{42}$ There is no indication that these long-standing restrictions are temporary and address a critical shortage of gas in the US domestic market, so as to fall outside of this prohibition by virtue

37 See Howse and Josling, Agricultural Export Restrictions and International Trade Law, supra note 4. 38 Section 3 of the Natural Gas Act (NGA) (15 U.S.C. $\$ 717 b)$. Implementing regulations issued by the Department of Energy are codified in 10 CFR Part 590.

39 See generally K. Cobb, 'The Questionable Logic of US Natural Gas Exports', Resource Insights (24 February 2013) http://www.resilience.org/stories/2013-02-24/the-questionable-logic-of-u-s-natural-gasexports (last viewed 14 August 2013).

40 The difference in the approval process in respect of exports to FTA and non-FTA countries is illustrated in regular surveys of export applications published by the Department of Energy, http://energy. gov/fe/downloads/summary-lng-export-applications (status as of 7 August 2013).

41 See AP, Japan's TEPCO Gears up for US Shale Gas Imports (7 February 2013), http://finance. yahoo.com/news/japans-tepco-gears-us-shale-gas-imports-074004342--finance.html (last viewed 14 August 2013).

42 See, e.g., Council for Trade in Goods, Decision on Notification Procedures for Quantitative Restrictions, G/L/59/Rev. 1 (22 June 2012) (listing non-automatic licenses). See also parts of the panel report in the present case that dealt with export licenses, which the $\mathrm{AB}$ set aside on procedural grounds relating to Article 6.2 of the Dispute Settlement Understanding. This point was discussed above regarding the WTO panel ruling, supra note 17, at paragraphs 7.917-7.918 and 7.957-7.958. Note that the WTO's Import Licensing Agreement would not be applicable to the US regime of export licensing; see http://www. wto.org/english/docs_e/legal_e/23-lic.pdf. 
of Article XI.2(a). Furthermore, the exceptions of Article XX appear unavailable as well to the United States. Although the US export licensing regime seems to be motivated primarily by economic considerations, it must be recognized that shale gas extraction is considered by various stakeholders to create environmental concerns. Yet to the extent the United States would seek to justify its export restrictions on environmental grounds, it could not invoke conservation under XX (g) if only because it imposes no comparable limits on domestic production or consumption. Another difficulty the United States would have is the distinction it makes between FTA partners and non-FTA countries. As this distinction is not related to environmental concerns, it will likely run counter to the chapeau of Article XX. ${ }^{43}$ As a result, the present regime could not stay in place.

Interestingly, in the past, the GATT contracting parties and subsequently the WTO Members resisted the negotiation of an agreement on export licensing, fearing notably the repercussions on their sovereignty over natural resources. ${ }^{44}$ The Members may thus have avoided detailed disciplines on these export restrictions, but they cannot escape the bite of the WTO's general rules. In sum, with the mounting importance all WTO Members attach to securing access to natural resources, the Appellate Body has created a major, internationalist precedent with its ruling in China-Raw Materials.

43 See Appellate Body Report, Brazil-Measures Affecting Imports of Retreaded Tyres (DS332), at paragraph 227 (3 December 2007).

44 See P. C. Mavroidis, Trade in Goods, 2nd edn (Oxford University Press, 2012), 388. 